\title{
KEMAMPUAN BERPIKIR KRITIS MAHASISWA CALON GURU PADA MATERI KELISTRIKAN (Studi Deskriptif pada Mahasiswa Program Studi Pendidikan Fisika Universitas Tadulako Tahun Angkatan 2014)
}

\author{
Amrullah Maguna, Darsikin dan Marungkil Pasaribu \\ Fisikarula@rocketmail.com \\ Program Studi Pendidikan Fisika FKIP Universitas Tadulako \\ Jl. Soekarno Hatta Km. 9 Kampus Bumi TadulakoTondo Palu - Sulawesi Tengah
}

Penelitian ini bertujuan untuk mendeskripsikan keterampilan berpikir kritis mahasiswa pada materi listrik dinamis. Jenis penelitian yang digunakan adalah deskriptif-kualitatif. Subjek penelitian ini yaitu mahasiswa Program Studi Pendidikan Fisika tahun angkatan 2014 berjumlah 20 orang. Data diperoleh melalui tes berpikir kritis dan wawancara. Tes berpikir kritis terdiri dari 5 butir pertanyaan yang telah divalidasi oleh ahli. Hasil penelitian menunjukkan bahwa masing-masing indikator berpikir kritis yang diteliti berada pada kategori sangat kurang kritis. Indikator menganalisis memperoleh nilai tertinggi dari ke lima indikator berpikir kritis yang digunakan.

Kata Kunci: Berpikir Kritis; Kelistrikan

\section{Pendahuluan}

Pelajaran Fisika dianggap sebagai pelajaran yang sulit untuk siswa dari sekolah menengah ke universitas dan juga untuk orang dewasa dalam pendidikan pascasarjana. Ketidaksukaan terhadap fisika ini disebabkan karena peserta didik mengalami kesulitan belajar sains khususnya fisika[1].

Kesulitan yang dialami peserta didik menunjukkan kegagalan bahwa peserta didik belum memiliki kemampuan berpikir mendalam dalam menyelesaikan masalah fisika. Untuk mengatasi masalah tersebut diperlukan kemampuan berpikir kritis agar peserta didik terbiasa dan tidak kesulitan dalam menyelesaikan masalah fisika khususnya pada materi listrik dinamis.

Terkait kemampuan berpikir kritis, [2] memandang berpikir kritis sebagai kegiatan mengaplikasikan rasional, kegiatan berpikir yang tinggi, yang meliputi kegiatan menganalisis, mensintesis, mengenal dan memecahkan masalah, menyimpulkan, dan mengevaluasi.

Kemampuan berpikir kritis setiap individu berbeda-beda, tergantung latihan yang sering dilakukan untuk mengembangkan kemampuan berpikir kritisnya[3] menjelaskan bahwa melalui tes dengan indikator bertanya dan menjawab pertanyaan yang membutuhkan penjelasan, melakukan deduksi, melakukan induksi, membuat nilai keputusan, dan memutuskan suatu tindakan dapat meningkatkan kemampuan berpikir kritis seseorang.

Berkaitan dengan kemampuan berpikir kritis yang dimiliki mahasiswa, maka kemampuan berpikir kritis seseorang dapat dilacak melalui pemberian masalah dalam bentuk soal yang bervariasi. [4] dalam penelitiannya yang berjudul Collaborative Learning Enhances Critical Thinking menyatakan bahwa kemampuan berpikir kritis seseorang dapat diketahui dengan pemberian soal yang melibatkan analisis, sintesis, dan evaluasi dari suatu konsep.

Penelitian ini mengkaji tingkat kemampuan berpikir kritis yang dimiliki mahasiswa calon guru pada materi kelistrikan tahun angkatan 2014. Indikator berpikir kritis yang digunakan yaitu indikator sistematis menurut anggelo yang meliputi keterampilan menganalisis, keterampilan mensintesis, keterampilan mengenal dan memecahkan masalah, keterampilan menyimpulkan serta keterampilan mengevaluasi atau menilai [5]. Dalam penelitian ini peneliti ingin mengetahui bagaimana kemampuan berpikir kritis yang dimiliki mahasiswa fisika tahun angkatan 2014 serta materi kelistrikan yang diteliti dibatasi pada materi listrik dinamis yang dipelajari pada mata kuliah Fisika Dasar II. 


\section{METODE PENELITIAN}

Jenis penelitian ini merupakan penelitian deskriptif-kualitatif. Subjek penelitian yaitu mahasiswa Program Studi Pendidikan Fisika tahun angkatan 2014 berjumlah 20 orang yang dipilih menggunakan teknik purposive sampling. Kemudian 6 orang dari subjek penelitian diambil sebagai responden yang dipilih berdasarkan kategori tinggi, sedang, dan rendah.

Instrumen yang digunakan adalah tes kemampuan berpikir kritis materi listrik dinamis yang dibuat dalam bentuk soal-soal uraian sebanyak lima nomor dan setiap nomornya mengacu pada indikator sistematis Anggelo.

\section{HASIL DAN PEMBAHASAN}

Secara keseluruhan hasil analisis tes kemampuan berpikir kritis untuk materi listrik dinamis, diperoleh skor rata-rata sebesar 24,60, dengan simpangan baku 2,78 . Nilai tersebut berada pada kategori sangat kurang kritis berdasarkan kategorisasi [6].

Hasil kemampuan berpikir kritis untuk setiap indikator yang digunakan disajikan pada Tabel 3.1 berikut.

Tabel 3.1 Rangkuman Hasil Analisis Kemampuan Berpikir Kritis Mahasiswa

\begin{tabular}{|c|c|c|c|c|c|c|c|c|}
\hline \multirow[t]{2}{*}{ No } & \multirow[t]{2}{*}{ Indikator } & \multicolumn{6}{|c|}{$\begin{array}{l}\text { Jumlah Subjek yang } \\
\text { Menjawab per Indikator }\end{array}$} & \multirow[t]{2}{*}{$\bar{x}$} \\
\hline & & 5 & 4 & 3 & 2 & 1 & 0 & \\
\hline 1 & Menganalisis & 0 & 1 & 1 & 9 & 9 & 0 & \multirow{2}{*}{34} \\
\hline \multicolumn{2}{|c|}{ Persentase (\%) } & 0 & 5 & 5 & 45 & 45 & 0 & \\
\hline 2 & Mensintesis & 0 & 0 & 4 & 8 & 2 & 6 & \multirow{2}{*}{30} \\
\hline \multicolumn{2}{|c|}{ Persentase (\%) } & 0 & 0 & 20 & 45 & 5 & 30 & \\
\hline 3 & $\begin{array}{l}\text { Mengenal dan } \\
\text { memecahkan } \\
\text { masalah }\end{array}$ & 1 & 0 & 0 & 0 & 19 & 0 & \multirow[t]{2}{*}{24} \\
\hline \multicolumn{2}{|c|}{ Persentase (\%) } & 5 & 0 & 0 & 0 & 95 & 0 & \\
\hline 4 & $\begin{array}{l}\text { Menyimpulka } \\
\mathrm{n}\end{array}$ & 0 & 2 & 0 & 2 & 5 & 11 & \multirow{2}{*}{17} \\
\hline \multicolumn{2}{|c|}{ Persentase (\%) } & 0 & 10 & 0 & 10 & 25 & 55 & \\
\hline 5 & $\begin{array}{l}\text { Mengevaluasi } \\
\text { atau menilai }\end{array}$ & 0 & 0 & 0 & 5 & 8 & 7 & \multirow{2}{*}{18} \\
\hline & rsentase (\%) & 0 & 0 & 0 & 25 & 40 & 35 & \\
\hline
\end{tabular}

Tabel 3.1 menunjukkan nilai yang diperoleh mahasiswa untuk setiap indikator yang digunakan masih sangat kurang. Indikator menganalisis menjadi aspek dengan nilai tertinggi dari 5 indikator berpikir kritis yang digunakan. Nilai tersebut masih tergolong sangat kurang karena nilai tersebut berada pada kategori sangat kurang kritis sesuai dengan tabel kategorisasi kemampuan berpikir kritis yang digunakan.

Penelusuran kemampuan memahami soal baik pemahaman konsep maupun matematis dilakukan melalui wawancara berdasarkan kategori tinggi, sedang, dan rendah. Hasil wawancara diketahui bahwa responden kurang memahami materi (konsep dan persamaan) kecuali satu responden yaitu $R$ 04. Selain itu, ditemukan pula responden yang masih kesulitan menganalisis katakata, kurangnya kemampuan matematis dan kurangnya kesiapan responden ketika mengerjakan tes yang diberikan.

\subsection{Deskripsi Hasil Tes Kemampuan Berpikir Kritis Mahasiswa}

Setelah melakukan analisis terhadap hasil tes kemampuan berpikir kritis pada mahasiswa, diperoleh beberapa data sebagai berikut.

Hasil penelitian yang dilakukan diperoleh nilai rata-rata skor setiap indikator adalah keterampilan menganalisis sebesar 34, keterampilan mensintesis sebesar 30 , keterampilan mengenal dan memecahkan masalah sebesar 24, keterampilan menyimpulkan sebesar 17 , dan yang terakhir keterampilan menilai atau mengevaluasi sebesar 18. Dari hasil penelitian, subjek-004 memperoleh nilai tertinggi dengan nilai 60 dan yang terendah yaitu subjek-017 dengan nilai 12.

Hasil penelitian menunjukkan bahwa 1 subyek berada pada kategori kurang kritis dengan nilai sebesar 60, sementara 19 subjek memperoleh nilai berfariasi dari nilai 12 sampai dengan 44 dan nilai ini berada pada kategori sangat kurang kritis.

Untuk soal nomor 1 , total nilai yang berhasil diperoleh adalah 34, atau sebesar $34 \%$ dari total nilai maksimum yang bisa dicapai secara keseluruhan (100). Pada soal nomor satu, ada satu subjek penelitian yang berhasil menjawab sampai dengan penilaian empat. Pada soal ini pula diketahui bahwa subjek penelitian belum mampu memberikan informasi sampai dengan penilaian 5. Hal ini dikarenakan subjek penelitian mengalami kekeliruan pada saat menerapkan konsep beda potensial pada burung yang bertengger pada kawat terentang bertegangan tinggi sehingga sebagian besar subjek penelitian 
memberikan informasi pada penilaian 2 dan 1.

Untuk soal nomor 2, total nilai yang berhasil diperoleh adalah 30, atau sebesar $30 \%$. Pada nomor ini, nilai tertinggi yang diperoleh subjek penelitian sampai dengan penilaian 3. Pada soal ini pula diketahui bahwa subjek penelitian belum mampu memberikan informasi sampai dengan penilaian 4 dan 5 . Hal ini dikarenakan kekeliruan subjek penelitian dalam memahami arti pembatas daya $2 \mathrm{~A}$ yang menyebabkan kurang sempurnanya jawaban yang diberikan.

Untuk soal nomor 3, total nilai yang berhasil diperoleh adalah 24, atau sebesar $24 \%$. Pada nomor ini, ada satu subjek penelitian yang berhasil menjawab soal dengan benar dan memperoleh nilai sempurna. Pada soal ini pula diketahui bahwa 19 subjek penelitian sudah mencoba menjawab permasalahan yang diberikan namun hanya mampu memberikan informasi pada penilaian 1. Hal ini dikarenakan kesalahan subjek penelitian dalam mengenali jenis rangkaian yang disajikan di dalam soal yang berdampak pada kesalahan dalam menentukan langkah-langkah penyelesaian yang digunakan.

Untuk soal nomor 4, total nilai yang berhasil diperoleh adalah 17, atau sebesar $17 \%$. Pada nomor ini, ada dua subjek penelitian yang mampu memberikan informasi sampai penilaian 4. Pada soal ini diketahui pula bahwa subjek penelitian belum mampu memberikan informasi pada penilaian 5 dan 3 . Selain itu, sebanyak 11 orang subjek penelitian tidak mampu memberikan informasi mengenai permasalahan yang diberikan sehingga diberikan nilai 1 . Hal ini dikarenakan subjek penelitian kesulitan menentukan langkahlangkah yang akan diambil dalam memberikan kesimpulan, sehingga mereka tidak mampu menjawab atau memberikan solusi yang tepat dari permasalahan tersebut. Selain itu, kurangnya kesiapan subjek ketika mengerjakan permasalahan menjadi faktor penyebab ketidakmampuan dalam memberikan kesimpulan sesuai permasalahan yang diberikan

Untuk soal nomor 5, total nilai yang berhasil diperoleh adalah 18, atau sebesar $18 \%$. Pada nomor ini, nilai tertinggi yang diperoleh subjek penelitian hanya sampai penilaian 3. Hal ini dikarenakan subjek penelitian masih sulit dalam memilih langkah-langkah yang tepat untuk digunakan dalam menjawab masalah yang diberikan. Sehingga berakibat pada hasil jawaban subjek yang sebagian besar menjawab keliru yang didasarkan atas penerapan langkahlangkah penyelesaian yang juga dipilih secara keliru. Selain itu, sebagian subjek menyelesaikan masalah hanya berdasarkan logika semata tanpa adanya pengetahuan yang mendasari logika tersebut.

\subsection{Analisis Data Untuk Masing-Masing Indikator}

Berdasarkan analisa data hasil pekerjaan dan wawancara mahasiswa tentang kemampuan berpikir kritis, diperoleh hasil untuk tiap-tiap indikator yang disajikan dalam uraian berikut:

\section{1) Kemampuan Menganalisis}

Pada soal pertama indikator menganalisis, nilai rata-rata subjek penelitian yang diperoleh sebesar 34. Dari 20 subjek penelitian, ada satu subjek yang mampu menjawab dengan skor 4 (Subjek-013). Berikut kutipan jawaban subjek-013.

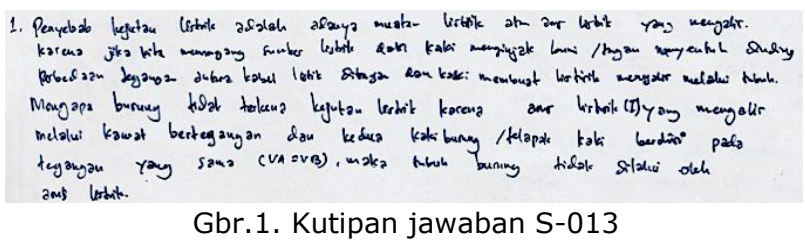

Pada indikator menganalisis subjek penelitian diminta menuliskan penyebab kejutan listrik serta menganalisis bagaimana seekor burung yang bertengger pada kawat terentang bertegangan tinggi tidak terkena kejutan listrik. Beberapa subjek mampu mengetahui penyebab dari kejutan listrik. Namun ketika menerapkan konsep kejutan listrik, subjek masih terlihat kesulitan. Berikut kutipan jawaban responden (R-14).

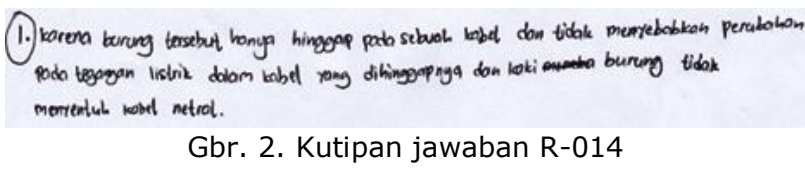

Pada saat wawancara responden (R-14) mengatakan menjawab masalah yang diberikan dengan cara menuliskan apa yang tersirat di pikiran responden.

Secara keseluruhan, hasil wawancara dengan responden penelitian ditemukan bahwa sebagian besar subjek penelitian dalam menganalisis melakukan kekeliruan pada saat melakukan identifikasi informasi 
dari soal yang diberikan. Ada pula yang tidak mampu melakukan identifikasi terhadap permasalahan yang diberikan dalam soal sehingga berdampak pada ketidakmampuan dalam menjawab tes yang diberikan. Kebanyakan subjek dalam menjawab informasi sebatas apa yang tersirat dalampikiran mereka setelah membaca soal.

\section{2) Keterampilan Mensintesis}

Pada soal nomor 2 indikator mensintesis, nilai rata-rata yang diperoleh subjek penelitian sebesar 34. Untuk soal indikator mensintesis, subjek diminta menyebutkan alat-alat yang dapat digunakan pada sebuah rumah apabila rumah tersebut menggunakan pembatas daya 2A. Pada kasus ini, sebagian besar subjek penelitian dalam memahami informasi soal masih kurang. Berikut kutipan Jawaban salah satu responden penelitian ( $R-$ 006).

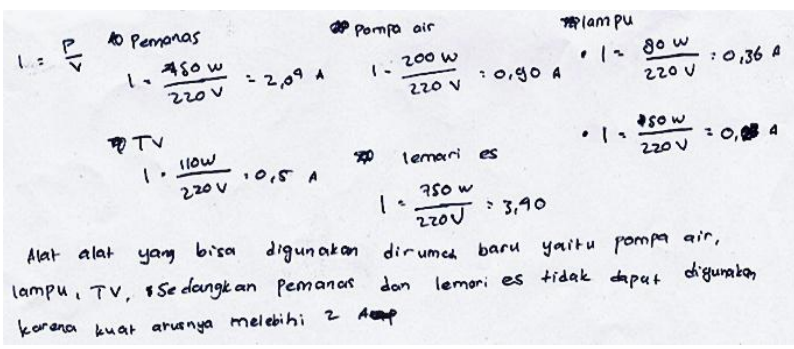

Gbr. 3. Kutipan jawaban R-006.

Dari kutipan jawaban di atas terlihat bahwa responden menentukan alat-alat yang dapat digunakan dengan melihat nilai kuat arus masing-masing alat dan melihat alat mana saja yang nilai kuat arusnya tidak melebihi pembatas daya 2A.Pada saat wawancara, responden mengatakan melihat nilai kuat arus dari masing-masing alat yang tidak melewati pembatas daya $2 \mathrm{~A}$.

Ketidakmampuan subjek penelitian dalam menyatukan semua informasi yang diperoleh dari soal, berdampak pada kekeliruan subjek dalam menentukan hasil akhir. Hasil wawancara ditemukan pula bahwa responden belum memahami sepenuhnya arti dari pembatas daya, sehingga dalam menentukan alat-alat yang digunakan, responden cenderung keliru. Hal ini membuktikan bahwa kemampuan mahasiswa pada tahap mensisntesis masih kurang.

3) Keterampilan Mengenal dan Memecahkan Masalah

Pada soal nomor 3 nilai rata-rata yang diperoleh subjek penelitian sebesar 30 . Pada tahap ini, satu subjek mampu menjawab sampai penilaian 5 yaitu R-004. Pada tahap mengenal dan memecahkan masalah, subjek diminta untuk menghitung besarnya kuat arus pada rangkaian, di mana rangkaian tersebut merupakan rangkaian jembatan Wheatstone. Namun pada soal yang diberikan, gambar rangkaian dibuat seolaholah merupakan rangkaian seri-paralel hambatan listrik sehingga subjek penelitian dituntut betul-betul mengenal jenis rangkaian serta mampu memecahkan masalah.

Secara garis besar subjek mampu mengidentifikasi informasi serta mampu menyelesaikan masalah. Kekeliruan subjek yaitu belum mampu mengenal dengan baik jenis rangkaian yang diberikan. Berikut kutipan jawaban salah satu responden ( $R$ 003).

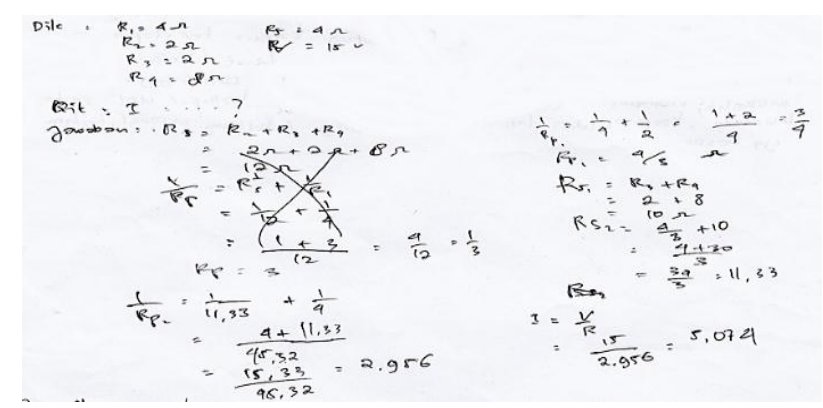

Gbr. 4. Kutipan jawaban R-003.

Dari kutipan jawaban di atas terlihat bahwa responden menyelesaikan masalah dengan menggunakan langkah-langkah penyelesaian seri-paralel hambatan listrik. Dari hasil wawancara diketahui bahwa responden memilih langkah tersebut dikarenakan gambar pada soal yang diberikan merupakan gambar rangkaian seri-paralel.

Pada dasarnya untuk dapat memecahkan masalah dengan perencanaan penyelesaian permasalahan yang matang, diperlukan keterampilan dan pemahaman tentang berbagai strategi pemecahan masalah. R-003 sudah mencoba menjawab permasalahan dari soal yang diberikan walaupun tidak tepat. Olehnya itu gambaran ide atau kelancaran dalam berpikir adalah salah satu cara yang baik dalam menyelesaikan masalah meski terkadang sering kali kurang tepat.

4) Keterampilan Menyimpulkan

Pada indikator menyimpulkan, subjek diberikan tes berupa sebuah hasil 
Percobaan. Pada percobaan tersebut diperoleh nilai kuat arus (I) untuk masingmasing hambatan (RC). Subjek kemudian diminta memberikan kesimpulan serta memverifikasi data pada tes tersebut. Pada tahap ini diperoleh nilai rata-rata sebesar 17. Hasil penelitian menunjukkan 2 subjek penelitian menjawab pada kategori penilaian 4 yaitu R-002 dan R-004.

Sebagian subjek penelitian diketahui belum mampu menarik kesimpulan yang benar serta tidak mampu memverifikasi data yang diberikan. Berikut kutipan jawaban salah satu responden ( $R-17)$.

kuat arus berbanding lurus dengan hambatan

Gbr. 5. Kutipan jawaban R-017.

R-17 hanya mampu menuliskan kesimpulan kuat arus sebanding dengan hambatan. Pada saat wawancara, responden mengatakan lebih baik memberikan kesimpulan yang tidak beralasan daripada tidak memberikan informasi pada lembar jawaban.

Kurangnya fokus mahasiswa mengelola informasi yang disajikan ternyata memberikan pengaruh cukup besar bagaimana mereka menarik kesimpulan. Hal ini terlihat sebanyak $25 \%$ subjek mampu memberikan kesimpulan namun masih keliru sehingga diberikan poin 1.

5) Keterampilan Mengevaluasi atau Menilai

Pada soal kelima indikator mengevaluasi atau menilai diperoleh nilai rata-rata subjek penelitian dalam menjawab soal tersebut sebesar 18. Subjek penelitian banyak melakukan kekeliruan dikarenakan belum mampu melakukan pemikiran yang matang dalam menentukan nilai serta menjawab informasi dengan baik. Ini terbukti ketika soal menanyakan bagaimana terang redupnya kedua lampu serta dibuktikan dengan menggunakan konsep hukum Ohm, sebagian besar subjek penelitian mampu menunjukkan terang redupnya kedua lampu. Namun, pada saat membandingkan terang redupnya kedua lampu sebagian subjek penelitian menentukan jawaban cukup dengan melihat besarnya tegangan yang diberikan.

Berikut salah satu kutipan jawaban responden (R-004).

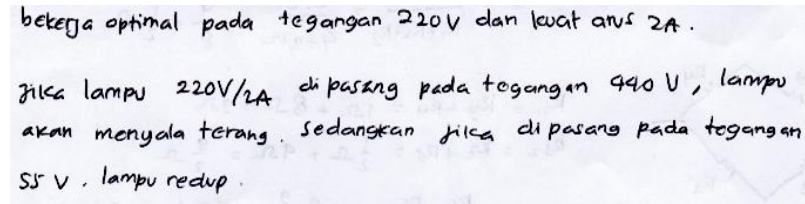

Gbr. 6. Kutipan jawaban R-004.

Pada dasarnya subjek penelitian masih kesulitan memilih langkah-langkah yang tepat untuk digunakan dalam menjawab masalah yang diberikan. Hal ini berakibat pada hasil jawaban subjek penelitian yang kebanyakan menjawab keliru yang didasarkan atas penerapan langkah-langkah penyelesaian soal yang juga dipilih secara keliru. Selain itu, sebagian subjek menyelesaikan masalah hanya berdasarkan logika semata tanpa adanya pengetahuan yang mendasari logika tersebut.

Secara keseluruhan dapat disimpulkan, bahwa pada penelitian ini kemampuan berpikir kritis mahasiswa fisika tahun angkatan 2014 belum mampu mencapai level kritis. Dari total 20 subjek penelitian, 1 subjek penelitian berada pada kategori kurang kritis, sedangkan 19 subjek lainnya berada pada kategori sangat kurang kritis. Beberapa faktor yang menyebabkan rendahnya kemampuan tersebut diantaranya kurangnya kesiapan subjek penelitian dalam menjawab masalah yang diberikan serta masih kurangnya kemampuan berpikir kritis yang dimiliki mahasiswa. Selain itu, ketidakmampuan peneliti menemukan prosedur pengukuran yang tepat terhadap kemampuan berpikir kritis mahasiswa juga menjadi faktor utama.

\section{KESIMPULAN}

Kemampuan berpikir kritis mahasiswa calon guru fisika tahun angkatan 2014 yang dibatasi pada materi listrik dinamis tergolong sangat kurang kritis. Hasil wawancara menunjukkan beberapa faktor yang mempengaruhi rendahnya kemampuan berpikir kritis mahasiswa yaitu mahasiswa cenderung memberikan informasi terkait masalah yang diberikan dengan menuliskan berdasarkan apa yang terlintas di pikiran mereka, bukan dengan pengetahuan bahwa mahasiswa tersebut memang benar-benar mengetahui jawaban dari masalah yang diberikan. Selain itu, kurangnya pengetahuan mahasiswa baik dalam memahami konsep maupun persamaan 
menjadi penyebab rendahnya kemampuan berpikir kritis mahasiswa.

Hasil penelitian juga menunjukkan nilai setiap indikator yang digunakan berada pada kategori sangat kurang kritis. Nilai tertinggi pada indikator yang digunakan adalah keterampilan menganalisis.

\section{DAFTAR PUSTAKA}

[1] Warimun, E. S. (2011). Peningkatan Penguasaan Konsep Melalui Pembelajaran Dengan Strategi Problem Solving Pada Topik Optika Bagi Mahasiswa Pendidikan Fisika. Jurnal Exacta. 9 (2) 2011.

[2] Filsaime, D. K. (2008). Menguak Rahasia Berpikir Kritis dan Kreatif. Jakarta: Prestasi Pustaka.

[3] Muyassaroh, L. (2013). Efektivitas Pembelajaran Berbasis Masalah Dengan OpenEnded Pada Materi Listrik Dinamis Terhadap Kemampuan Berpikir Kritis Siswa. Skripsi. Tidak Diterbitkan.

[4] Gokhale. (1995). Collaborative Learning Enhances Critical Thinking. Journal of Technology Education. 7 (1).

[5] Santoso, H. (2009). Pengaruh Penggunaan Laboratorium Riil dan Laboratorium Virtual pada Pembelajaran Fisika Ditinjau dari Kemampuan Berpikir Kritis Siswa. Tesis. Solo: PPS UNS. Tersedia: http://core.ac.uk/download/pdf/12349393.pdf [10 Oktober 2014]

[6] Setiawan, A. (2012). Penerapan Model Pembelajaran Kooperatif Tipe NumberedHeadsTogether Berbasis Problem Solving Untuk Meningkatkan Kemampuan Berpikir Kritis Siswa. Skripsi pada Jurusan Fisika Fakultas MIPA Universitas Negeri Semarang. Tidak Diterbitkan. 